\title{
Leśmian przed Prawem Wartość życia i wzniosłość prawa
}

\section{Bezprzymiotnikowe życie}

Znaczenie bezwzględnej wartości życia w twórczości Leśmiana chciałabym ukazać, odwołując się do dwóch utworów poetyckich; są to ballada Asoka z tomu Łąka i opublikowany pośmiertnie wiersz z incipitem „Przez śnieżycę, co wyjąc, powiększa przestworza...". Mają one za tło skrajnie niepodobne do siebie krajobrazy kulturowe - legendarny świat starożytnych Indii i rzeczywistość społeczną dwudziestolecia międzywojennego, ów tak rzadko ukazywany przez Leśmiana, zdegradowany w sensie metafizycznym „pejzaż współczesny", by posłużyć się tytułem innego wyjątkowego wiersza. Trudno o większy kontrast - a jednak oba dzieła łączy niezachwiane przekonanie, że zabójstwo jest złem, a na straży życia, nie tylko ludzkiego, powinno stać prawo'.

Zagadnienie wzniosłości prawa, wspólne dla przywołanych utworów, jest o wiele bardziej nieoczywiste i wymaga przypomnienia wagi zagadnień społecznych, ekonomicznych i właśnie prawnych, poruszanych przez poetę w jego szkicach, co ukazał Jan Zięba ${ }^{2}$. Uwzględnienie poglądów wyrażanych

\footnotetext{
" Uniwersytet Jagielloński, Wydział Polonistyki, Katedra Historii Literatury Pozytywizmu i Młodej Polski, e-mail: anna.czabanowska-wrobel@uj.edu.pl.

1 Związki między prawem a literaturą przedstawia syntetycznie M. Jakubowiak, Nieuchronny plagiat. Prawo autorskie w nowoczesnym dyskursie literackim, Warszawa 2017, s. 19-35.

2 Zob. J. Zięba, Bolestawa Leśmiana światopogląd nowoczesny. O eseistyce poety, Kraków 2000; tenże, Pieniądz i stowo. Nowoczesne paradoksy Leśmianowskiego języka poetyckiego, „Teksty Drugie" 2010, nr 6, s. 227-237.
} 
przez Leśmiana $\mathrm{w}$ eseistyce bez tracenia $\mathrm{z}$ oczu perspektyw estetycznych i metafizycznych, jakie otwiera poezja, to trudność, z którą warto się zmierzyć. Relacje pomiędzy prawem a literaturą w twórczości absolwenta studiów prawniczych, jakim był Leśmian, to przy tym temat godny znacznie szerszej uwagi. Niezależnie od akcentowanej przez autora Znaczenia pośrednictwa w metafizyce życia zbiorowego opozycji między twórczą, stwarzającą naturą a „wtórą rzeczywistością” życia społecznego, w której przejawia się prawo pisane małą literą, także ta druga budziła jego zainteresowanie, również w poezji.

Słowa „w życiu nic nie ma, oprócz życia” ${ }^{3}$ nie są wypowiedzianą przez przypadek czy dla rymu Leśmianowską tautologią. Pojęcie życia to - zarówno u autora Łąki, jak i u jego rówieśników - kategoria absolutna, bezprzymiotnikowa i obywająca się bez definicji; nie jest ona przy tym zdeterminowana tylko biologicznie, a z pewnością rozważania poety o życiu nie są zależne wyłącznie od nauk przyrodniczych ${ }^{4}$. Autor Napoju cienistego zna inne sposoby układania opowieści o nim, ugruntowane w tradycji filozoficznej i w naukach społecznych, ale w swojej refleksji poetyckiej czerpie przede wszystkim z samej literatury, zaczynając od najdawniejszych, archaicznych dzieł ludzkości, starożytnych eposów, mitów i baśni.

W poezji Leśmiana nie brak formuł związanych z samym zjawiskiem życia, z intensywnością czystego istnienia; „,[...] to czujne, bezbrzeżne z całych sił - istnienie ${ }^{\prime \prime}$ staje się przedmiotem afirmacji na przekór śmierci, o której nigdy się tu nie zapomina. „Przyszedłem na ten świat / I nie chcę

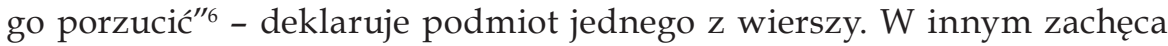
do przeżywania życia w czystej postaci, dla niego samego: „Trzeba nic nie mieć prawdziwie, / Żyć tylko tym, że się żyje"7. Michał Paweł Markowski akcentuje, że „życie” należy do najistotniejszych tematów Leśmiana:

Tak właśnie jest u Leśmiana: życie to żywioł najpotężniejszy, który wszystko zagarnia, który wszystkiemu nadaje znaczenie lub znaczenie odbiera. W tym sensie to nie człowiek żyje, ale życie się uczłowiecza (ale też wciela się w inne kreatury), dając człowiekowi jedynie iluzję sprawczości, a nie sprawczość samą ${ }^{8}$.

Ostatnie stwierdzenie warto rozwinąć, gdyż poczucie sprawczości pojawia się dopiero na płaszczyźnie społecznej (w tym także prawnej); co

3 B. Leśmian, Szewczyk, [w:] tegoż, Poezje zebrane, oprac. J. Trznadel, Warszawa 2010, s. 217.

4 Zob. G. Anidjar, Znaczenie życia, przeł. T. Bilczewski i A. Kowalcze-Pawlik, [w:] Teoria, literatura, życie. Praktykowanie teorii w humanistyce wspótczesnej, pod red. A. Legeżyńskiej i R. Nycza, Warszawa 2012, s. 227-266.

5 B. Leśmian, Z lat dziecięcych, [w:] tegoż, Poezje..., s. 386.

6 Tenże, $W$ słońcu, [w:] tegoż, Poezje..., s. 13.

7 Tenże, Pogoda, [w:] tegoż, Poezje..., s. 159.

8 M.P. Markowski, Życie, pieszczota, sztuka, śmierć, [w:] „Lecz nie było juź świata...". Bolesław Leśmian. Miłość iśmierć. Wiersze, całość ułożył, fotografie wykonał i słowem wstępnym opatrzył A. Nowakowski, Kraków 2017, s. 108-109. 
nie wyklucza uczestnictwa we wzajemnych relacjach także aktorów nieludzkich (a co właśnie zaznacza się w utworach Leśmiana, również tych fantastycznych).

\section{Jak gdyby. Wiersze-przypowieści}

Zaplecze filozoficzne Leśmianowskiego witalizmu to przede wszystkim koncepcje Bergsona, ale też, jeśli weźmiemy pod uwagę rozległy, choć nieusystematyzowany, charakter lektur poety, inne "filozofie życia” z początku XX wieku'. Żaden z filozofów nie jest przez niego traktowany jako niepodważalny autorytet; jego zdaniem każde myślenie opiera się na pewnego rodzaju fikcji, „baśni”, przyjętym bez dowodów założeniu. Jak o tym pisał w eseju Z rozmyślań o Bergsonie: „Nawet nauka, ścisła, logiczna nauka, nie może się obejść bez wzgardzonej przez siebie baśniowości"10. Wydane w roku 1911 dzieło Hansa Vaihingera Die Philosophie des Als Ob ukazywało rolę użytecznych fikcji, za których pomocą człowiek próbuje ujmować dostępną mu rzeczywistość ${ }^{11}$. Niezależnie od koncepcji niemieckiego myśliciela, Leśmian wyraża w szkicu z roku 1910 przekonanie o przemijającym charakterze hipotez nauki i filozofii.

Fikcja literacka staje się dla Leśmiana przestrzenią bezpiecznego eksperymentu ,jak gdyby", poetyckie utwory narracyjne są terenem, na którym twórca może bezkarnie sprawdzać dowolne założenia i ich przeciwieństwa. Siła Leśmianowskich wierszy-przypowieści kryje się w ich absolutnej wieloznaczności. Stanowią one rodzaj magicznego lustra, w którym interpretator zobaczy to, co wydaje mu się ważne: absurd istnienia i wierność Boga, okrucieństwo i współczucie, obojętność i wzajemność (skrajności te można wydobyć choćby z wiersza Marcin Swoboda, do którego odnosił się w swoim szkicu Markowski ${ }^{12}$, z ballady Strój, którą interpretował Ryszard $\mathrm{Nycz}^{13}$, czy z poematu Dziewczyna). Rozsunięcie między pozorowaną spójnością narracji a całkowitą destrukcją dawnych znaczeń doprowadzone jest do granic wyrażalności w ważnym programowym wierszu Słowa do pieśni bez słów $w^{14}$. W wielu utworach narracyjnych o spójnej fabule jest to mniej zauważalne, jednak także w nich obowiązuje nadrzędna zasada polegająca na łamaniu metodami poetyckimi stereotypowych przebiegów fabularnych właściwych

9 Zob. A. Bielik-Robson, Erros. Mesjański witalizm i filozofia, Kraków 2012 oraz B. Sienkiewicz, Filozofia życia vs. Koncepcja mechanistyczna. Od filozofii życia do posthumanizmu. Przypadek Leśmiana i Schulza, [w:] Młodopolski witalizm, modernistyczne witalizmy, pod red. A. Czabanowskiej-Wróbel i U.M. Pilch, Kraków 2016.

10 B. Leśmian, Z rozmyślań o Bergsonie, [w:] tegoż, Szkice literackie, oprac. J. Trznadel, Warszawa 2011, s. 10.

11 Zob. A. Janaszczyk, Na granicy neokantyzmu. O filozofii Hansa Vaihingera, Gdańsk 2010.

12 Markowski, dz. cyt.

13 R. Nycz, Wielowyktadalność. Symboliczne alegorie Leśmiana, [w:] tegoż, Tekstowy świat. Poststrukturalizm a wiedza o literaturze, Kraków 2000, s. 131-137.

14 Zob. M. Głowiński, Zaświat przedstawiony. Szkice o poezji Bolesława Leśmiana, Warszawa 1981, s. 57-63. 
dla "prostych form”. Taką rolę pełni choćby „powieść” układana przez tytułową bohaterkę wiersza Lalka. Wykładnie parabol poetyckich, fabuł, które dają się pomyśleć, są niejako w pisane w zamiar nierozstrzygalności. Intencją poetyckich działań Leśmiana bywa destrukcja powszechnie przyjmowanego sposobu myślenia, ale najgłębszy cel ma charakter gestu mesjańskiego. Rodolphe Gasché napisał o Kafce, odwołując się do myśli Waltera Benjamina:

Do zbawienia można dotrzeć od strony jego podszewki. Choć pozostaje całkowicie odmienny, świat mitu stanowi spodnią stronę świata objawienia. Niewiele trzeba - choć niewiele jest tutaj wszystkim - by przewlec jedną stronę na drugą ${ }^{15}$.

\section{Dobre Prawo}

Nie wolno zabijać - ta idea opanowuje wojownika i władcę - Asokę, który „rozżalił się duchem” na widok poległych wrogów. W wyniku wewnętrznej przemiany postanawia zmienić prawa swojego państwa i zakazać wszelkiej przemocy. Bohater Leśmiana wypowiada w performatywny sposób słowa potrójnej przysięgi:

[...] „Odtąd niech wrogów nie będzie na świecie,

Niech łzom stanie się zadość, niech spoczną zamiecie -

Tak przysięgam : po pierwsze, po wtóre, po trzecie!"

I ukląkłszy na mieczu, jak klęczą mocarze,

Poukochał kolejno te rany, te - wraże,

I zgromadził w pamięci przewymarłe twarze ${ }^{16}$

Bohater jest postacią historyczną, prawodawcą starożytnych Indii, który stał się również tematem wielu legend. Jego imię, inaczej niż w przypadku postaci z wiersza zatytułowanego Asoka, będzie tu zapisywane jako Aśoka. Historyczny władca, pochodzący z dynastii Maurjów, żył w latach 304-232 p.n.e.; jego imperium obejmowało przede wszystkim tereny Indii, Pakistanu i Afganistanu. Po zwycięskiej wojnie z Kalingą, państwem położonym na terenie dzisiejszych Indii, Aśoka przechodzi głęboką przemianę - z okrutnego wojownika staje się łagodnym prawodawcą ${ }^{17}$. Życzliwość, szacunek, wspaniałomyślność, szczerość, prawdomówność, czystość serca, entuzjazm, wierność, samokontrola, wyrzeczenie się przemocy stanowiły odtąd istotę

15 R. Gasché, Prawo Kafki: w polu sił między judaizmem a hellenizmem, przeł. N. Rapp, [w:] Nienasycenie. Filozofowie o Kafce, red. Ł. Musiał i A. Żychliński, Kraków 2011, s. 354.

16 B. Leśmian, Asoka, [w:] tegoż, Poezje..., s. 261.

17 Legendy wyostrzają kontrast między wcześniejszym okrucieństwem króla mordującego przeciwników politycznych i krewnych a zachowaniem bohatera po przemianie w dobrego władcę. 
ustanowionego przez niego Dobrego Prawa, którego zasady nakazał wyryć na wielu kolumnach, obeliskach czy budowlach w całym kraju:

Oto skrucha ogarnęła Miłego Bogom Króla z powodu zwycięstwa nad krajem Kalingów. Bo gdy wolny kraj zostaje zdobyty, powoduje to ofiary w zabitych oraz śmierć i deportację ludzi. Myśl o tym odczuwa Król Miły Bogom nad miarę boleśnie jako poważne obciążenie ${ }^{18}$.

Przemianę Aśoki łączono z jego buddyjskim nawróceniem, jednak polityczny zamysł i propagowanie tolerancji wykraczały poza jedną religię. Badania dwujęzycznych inskrypcji Aśoki, zapisanych po grecku i aramejsku, pochodzących z Kandaharu i Dżalalabadu, dały uczonym wyobrażenie o skali, także moralnej, jego przedsięwzięcia obliczonego na długie trwanie (nadzieja ta nie została spełniona i imperium Aśoki nie przetrwało po jego śmierci). Królewscy tłumacze uwzględniali więc także tradycje greckie, gdy buddyjskie pojęcie prawa (dhamma) oddawali jako eusebia (uczciwość, pobożność) ${ }^{19}$.

Co istotne dla poematu Leśmiana, historyczny Aśoka nakazał budowanie schronisk dla pielgrzymów, jako miejsc, w których znajdowały się drzewa dające cień, i lecznic dla chorych istot (nie tylko dla ludzi). W syntezie dziejów powszechnych wydanej w dwudziestoleciu międzywojennym, kiedy to wiersz Leśmiana był już opublikowany, Eugeniusz Słuszkiewicz pisał:

Na rozkaz cesarza sadzono wzdłuż gościńców drzewa figowe dla cienia, a mangowe dla owoców, kopano studnie, budowano szopy dla podróżnych, troszczono się o biednych i opiekowano chorymi ${ }^{20}$.

Warto przyjrzeć się uważnie temu, co Leśmian wydobywa z opowieści o Aśoce, gdyż sama sekwencja zdarzeń podpowiada jej sens. Przemiana duchowa, rezygnacja z przemocy, ustanowienie dobrego prawa, bezinteresowna pomoc dla żywej (radykalnie innej) istoty, wdzięczność i wzajemność, wyzbycie się ograniczeń związanych z własnym „,ja” skutkują wewnętrzną harmonią i przynoszą duchowe dary. W proponowanym odczytaniu ograniczam do minimum oczywisty tu kontekst buddyjski, by zaakcentować to, co uniwersalne, a równocześnie niezależne od kulturowego kolorytu opowieści.

18 Orędzia króla Asioki, przeł. J. Makowiecka, Warszawa 1964, s. 20, cyt. za: M. Marczewska-Rytko, Asioka jako twórca buddyzmu społecznego, "Annales UMCS” 1997, vol. 4, s. 165.

19 J. Fedirko, Kandaharskie inskrypcje króla Aśoki, „Peregrinus Cracoviensis” 2014, nr 2, s. 72. Autor przywołuje opinię Anny Świderkówny, która podkreślała uniwersalny charakter przesłania Aśoki i związki przekładu orędzia z kulturą grecką: „Można by po prostu sądzić, że mamy do czynienia z fragmentami greckiej literatury filozoficznej!”. A. Świderkówna, Hellenika. Wizerunek epoki od Aleksandra do Augusta, Warszawa 1978, s. 264.

20 E. Słuszkiewicz, Historia Indii, [w:] Wielka historia powszechna, pod red. J. Dąbrowskiego, O. Haleckiego, M. Kukiela, S. Lama, t. 1, J. Bromski, J. Czekanowski, J. Jaworski, J. Kostrzewski, T. Narolewski, S. Przeworski, E. Słuszkiewicz, J. Smoleński, Pradzieje ludzkości i historia państw Wschodu, Warszawa 1935, s. 376. 
Uratowane baśniowe drzewo odwdzięcza się człowiekowi, a wdzięczność przeradza się w bezwarunkowe uczucie. Asoka za swoje decyzje i działania zostaje niejako nagrodzony bezinteresowną i „niepotrzebną” miłością wierzby, której wcześniej udzielił pomocy. Dobro rodzi tu dobro, tak jak w wielu innych Leśmianowskich parabolach zło wywołuje zło, brak miłości skutkuje poczuciem pustki, a miłość - na przekór absurdalności istnienia obdarza. Gdyby wydawało się to zbyt proste i nazbyt optymistyczne, mamy pamiętać, że dzieje się tak jedynie w opowieści.

\section{Żywe życie}

Leśmian nazywa legendarne drzewo króla Asoki „wierzbą” i jest to najlepsza możliwa decyzja - nieznane w Europie drzewo asioka (Saraca indica lub Saraca asioka) należące do rodziny bobowatych zyskuje w polszczyźnie neutralną i zrozumiałą nazwę o jednoznacznie żeńskim aspekcie, symbolicznie nacechowaną związkami z wodą, płaczem (dodatnio u poety wartościowanym) i słabością. Prawdziwe drzewo asioka było czczone w Indiach i jest uznawane do dziś za lecznicze (w tym dobroczynne dla kobiet pragnących potomstwa). W jego cieniu miał przyjść na świat Budda, rośliny te sadzono więc w okolicach buddyjskich pustelni. Delikatne, czerwone kwiaty asioki pełniły również ważną funkcję w obrzędach hinduistycznych, a legendy dotyczące drzewa były powiązane z opowieściami o miłości Ramy i jego żony Sity.

Przekazy na temat historycznego króla obrosły w legendy związane z drzewami i dają się sprowadzić do kilku wariantów, w których istotne jest przywiązanie władcy do asioki, a także swoiste zrównanie - za sprawą imienia - losów człowieka i rośliny. Aśoka spędza pod ulubionym drzewem wiele czasu, medytuje i sprawuje władzę w jego cieniu, wręcz utożsamia się z nim, co prowadzi do nieporozumień z kobietami z królewskiego haremu, wreszcie, pod koniec życia „usycha” i umiera w jego pobliżu ${ }^{21}$. W jednej z popularnych legend cały harem lub jedna z małżonek z zazdrości niszczy wybrane przez męża drzewo, którym bywał również inny ceniony w Indiach gatunek muszkatowiec. Władca pogrążony w rozpaczy ratuje swoją roślinę, lecząc ją mlekiem i nie opuszczając jej ani na chwilęe22. Autor Poematów zazdrosnych nie rozwinął motywu zazdrości małżonki (czy też wielu żon) króla o ukochane drzewo, musiałby wówczas wprowadzić elementy okrucieństwa i zemsty, których poemat jest pozbawiony. Narrator wspomina tylko o zrozumiałym zapomnieniu władcy - otoczonego przez piękne dziewczęta - o wierzbie, „bo któż to spamięta?”. Jednak w paradoksalny sposób brak kochającej istoty daje o sobie znać nawet podczas świątecznych tańców. Asoka „[...] czuł, że

21 Zob. J. Strong, The Legend of King Aśoka. A Study and Translation of Asokāvadāna, Delhi 2008, tu zwłaszcza rozdział The Aśoka Tree, s. 127-130. 2005, s. 53.

22 J. Krzyżowski, Cudowne odrodzenie muszkatowca, [w]: tegoż, Legendy króla Asioki, [b.m.] 
tchom dziewczęcym brak jakichś korali, / I że coś powierzbnego w duszy mu się żali"23.

Leśmian przemyślał istotę legend o Aśoce i jego roślinnej imienniczce w stylizowanej szacie poematu ukazuje tajemniczą więź łączącą człowieka i drzewo ${ }^{24}$. W wywiadzie udzielonym Edwardowi Boyé powołuje się na ten utwór, gdy wyjaśnia rozmówcy swoje poglądy: „Miłość moja do natury była zawsze konkretna. Przecież w wierszu Asoka wierzba przychodzi do króla i wyznaje mu swoją najprawdziwszą, rzeczywistą miłość"25. Naturalne w tym

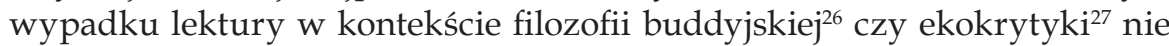
zamykają drogi do innych odczytań, w których najważniejszy jest uniwersalny sens miłości przekraczającej wszelkie granice ( $w$ tym także granice królestw przyrodniczych). Uczucie uratowanego drzewa jest $\mathrm{z}$ początku wdzięcznością, później nie wymaga już żadnego uzasadnienia, stając się afirmacją istnienia Drugiego w całej jego odmienności, i daje się zrozumieć tylko w tautologicznych formułach, znanych poezji miłosnej na całym świecie, „bo ty to ty", tylko ty jesteś tobą.

W tomie Łąka wzajemna bliskość i zatarcie granic następuje między Bogiem a fantastycznym drzewem w balladzie $D a ̨$, natomiast przeciwieństwem bezinteresownej relacji króla i wierzby jest sytuacja z ballady Wiśnia, której tytułowa bohaterka odmawia człowiekowi wzajemności i powtarza: „Ach, nie po to się czerwienię, / żeby gasić twe pragnienie!"28. Postać ludzka staje się tu figurą niespełnionego pożądania, zatrzymanego na wieczność. Doskonała miłość Asoki i nieodwzajemnione uczucie bezimiennego króla mają jednak wspólny mianownik - obdarzają nieśmiertelnością („Ona z dawna przez jego kochanie / Nieśmiertelne pozyskała trwanie"29 - czytamy w Wiśni).

W świetle tradycji Wschodu, bliskiej historycznemu Aśoce, ujawnia się duchowa strona więzi dwóch niepodobnych do siebie istot, wzmocniona $\mathrm{w}$ oryginalnych przekazach indyjskich tożsamością ich imienia z przeczącym przedrostkiem $a$-, które znaczy w sanskrycie: „bez troski”, pozbawiony smutku czy też cierpienia. Mistyczna formuła hinduizmu, znana też w buddyzmie, tat tvam asi - „ty jesteś tym” - staje się w tym świetle czymś naturalnym.

23 B. Leśmian, Asoka, s. 262.

24 Zob. J. Tuczyński, Motywy indyjskie w literaturze polskiej, Warszawa 1981; H. Marlewicz, Leśmian - indyjskie inspiracje, "Perspektywy Kultury” 2009, nr 1, s. 69-84; I. Milewska, The "Mahabharata" Epic, Its Translations and Its Influence on Polish Intellectual Circles and General Readers, „Iuvenilia Philologorum Cracoviensium” 2012, t. 5, s. 287-315.

25 B. Leśmian, Dialogi akademickie - w niepojętej zieloności [rozmowę przeprowadził Edward Boyé], [w:] Szkice..., s. 547.

26 Już Adam Szczerbowski wskazywał na religijne motywy działań Aśoki, który „przyjąwszy naukę Wyzwolonego, stawiać kazał dla ludzi, zwierząt i roślin szpitale, aby wcielić w życie naukę Doskonałego”. A. Szczerbowski, ,"Brzegiem szału w niepojętość zieloności”. O „Еące” Bolesława Leśmiana, Warszawa 1934, s. 30.

27 Wątki ekokrytyczne poezji Leśmiana zostały podjęte przez Darię Lekowską na konferencji „Leśmian od nowa”, Łódź, 6-8 listopada 2017.

28 B. Leśmian, Wiśnia, [w:] tegoż, Poezje..., s. 178.

29 Tamże. 
U Leśmiana Asoka początkowo nie może odwzajemnić uczuć drzewa, by nieoczekiwanie odkryć swoją wzajemność:

Król Asoka z pałacu wybiegł na spotkanie

I wyciągnął ramiona i poglądał na nie,

Że się tak wyciągnęły i tak niezachwianie.

I przybyłej sam wskazał wcieleniem swej dłoni,

Kędy ma się zielenić i w jakiej ustroni - ${ }^{30}$

Spontaniczne działanie obywa się bez słów i jest wyrazem reakcji ciała i psychiki jako jedności; mówiąc w języku Młodej Polski - wcielonej duszy, a w koncepcjach współczesnej nauki - ucieleśnionego umysłu. Refleksja bohatera ex post obejmuje szereg rodzących się emocji, które - dopiero gdy je on u siebie zauważa - może uznać za podobne do samej miłości. Asoka mówi:

"[...] Czuję szczęście, gdy duszę w twoją zieleń wyślę,

Do miłości podobne tak bardzo, tak ściśle,

Że jest samą miłością, skoro się zamyślę...”31.

Tak pojmowany stan jest, pomimo niewspółmierności relacji człowieka i drzewa, „samą miłością”. Dobitny ton poematu, wzmocniony przez potrójne, dokładne rymy w każdej jego tercynie (aaa, bbb) i baśniowa fabuła budują naiwną siłę opowieści ze szczęśliwym zakończeniem, której delikatny humor jest niebezpiecznie bliski bolesnej ironii.

Poemat Leśmiana jest z pewnością wieloznaczny, zwłaszcza gdy chodzi o możliwe konteksty jego interpretacji, jednak fundamentalne znaczenie utworu podpowiada logika samej opowieści. Warunek duchowej harmonii to rezygnacja z przemocy i zadeklarowanie jako obowiązującej zasady: nie wolno zabijać. Miłość, jaką obdarzony został bohater, ufundowana jest na przekonaniu o wartości samego życia.

\section{Pod prawem czy przed Prawem?}

„Wtóra rzeczywistość”, życie społeczne jako główny temat pojawia się w wierszach Leśmiana znacznie rzadziej wobec tematyzowanej w tak wielu utworach (zwłaszcza w tomie Łąka) utopii bezpośredniości i zawsze na pewien sposób spleciona jest z tym, co należy do sfery twórczej natury; dlatego ważne są wyjątki potwierdzające regułę. Taki utworem jest rewelacyjny

30 Tenże, Asoka, s. 262. Z kolei w balladzie Dąb Bóg „,biegł żywcem do grajka i wyciągał swe dłonie”. Tenże, Dąb, [w:] tegoż, Poezje..., s. 191. Ze względu na znaczenie, jakie ma określenie „żywcem” w kolejnym wierszu, sygnalizuję, że mimo groteskowej konwencji, ujawnia tu się idea Boga żywego.

31 Tenże, Asoka, s. 263. 
w swoich skrótowych, drapieżnych diagnozach społecznych Pejzaż wspótczesny, którego akcja rozgrywa się, jak pamiętamy, w niedobrym „krwi pożywką podchmielonym czasie" ${ }^{\prime 32}$, gdy poezja straciła swój związek z metafizyką, a „porównanie się stało tylko - porównaniem”"33. Tu jedyny raz w utworze wierszowanym znajdujemy słowa takie jak „kolektyw”, który „tańczy tango dlatego, że mu się należy"34.

Takim utworem jest również mniej znany wiersz z incipitem „Przez śnieżycę, co wyjąc, powiększa przestworza..."; w pierwodruku w Dziejbie leśnej nadano mu tytuł Zbój. Jest to swego rodzaju odpowiedź Leśmiana na literaturę, która chce „życie w rodzajowe pokurczyć obrazki” - próba udowodnienia, że nawet bardzo przyziemna sytuacja może zostać ukazana w sposób, który nadbudowuje nad nią całe piętra znaczeń i obrazów (z wizerunkiem słabo ukrytego w obłokach Boga włącznie). Składający się z czterech strof wiersz pragnę przytoczyć $\mathrm{w}$ całości.

Przez śnieżycę, co wyjąc, powiększa przestworza, Zbój się skrada - w nawianej puszyściejąc bieli...

Nie masz prawa sięgania do ludzkiej gardzieli!

Mam - prawo noża!

Pcha go naprzód w mrok pusty wicher i nadzieja...

Stanął nagle, jak gdyby z durną zmorą zszedł się.

I oczy, zaszronione nieściśle, rozkleja

I patrzy przed się.

Z cieniem, który ułomnie zboczony na murze

Na przelewne ramiona wdział czapę bez głowy,

W sztywnym brzasku latarni piętrzy się w mundurze

Posterunkowy.

Księżyc na chmur czuprynę wyplusnął dzban mleka,

A Bóg żywcem uchodzi w śnieg, w chłód i w zawieję.

Zbój krzyczy: „Panie Chmura!” - i w nicość ucieka,

A on - olbrzymiejąc - poważnieje... ${ }^{35}$

Czas akcji jest tu bardzo krótki, ograniczony do jednego wyrazistego epizodu. Zbudowany z czterech strof czarno-biały (a ściślej - operujący kontrastem bieli i ciemnego granatu) uliczny obrazek prezentuje scenkę jak z teatru cieni, czy lepiej, z ówczesnego ekspresjonistycznego kina. Akcja

32 Tenże, Pejzaż wspótczesny, [w:] tegoż, Poezje..., s. 395.

33 Tamże.

34 Tamże.

35 Tenże, [Przez śnieżycę, co wyjąc, powiększa przestworza...], [w:] tegoż, Poezje..., s. 504. 
rozgrywa się w zimową noc, na zasypanej śniegiem ulicy, w słabym świetle latarni, na tle nieba i w blasku księżyca.

Fragment eseju Znaczenie pośrednictwa w metafizyce życia zbiorowego, pochodzącego z roku 1910, stanowi ważny kontekst do sytuacji zarysowanej w wierszu:

Powaga znaków i stanowisk jest między innymi zbawczym warunkiem bezpieczeństwa publicznego.

Zbrodniarz nieustraszenie napada na silniejszego odeń i lepiej uzbrojonego przechodnia. Natomiast cofa się lękliwie na widok słabszego fizycznie i nawet gorzej uzbrojonego urzędnika policyjnego. Nie obawa kary powstrzymuje go od zbrodni. Tak w jednym, jak w drugim wypadku obawa kary w jednakim stopniu mogłaby pohamować jego zbrodnicze chęci.

Na widok wszakże dowolnego pozornie znaku, mianowicie munduru - myśl zbrodniarza z osobistego, izolowanego świata przenosi się do świata międzyludzkiego, do świata znaków i stanowisk i sylogizmując się z danymi tego świata, zmienia swój poprzedni kierunek lub w ogóle sparaliżowana nagłą zmianą kierunku - przestaje istnieć ${ }^{36}$.

Skomentujmy, że termin „sylogizmować się” w tym wypadku nawiązuje do pojęcia sylogizmu prawniczego, oznaczającego czynność, w której ogólna, abstrakcyjna norma prawna jest zastosowana do stanu faktycznego ${ }^{37}$. Posługując się językiem użytym przez Leśmiana w eseju, proces myślowy, który dokonał się w natychmiastowym tempie w umyśle bohatera wiersza, można opisać jako subsumpcję; sytuacja, w której się znalazł, została przez niego przyporządkowana normie prawnej, której obowiązywanie przypomniał mu widok policyjnego munduru ${ }^{38}$.

Pierwszą z postaci pojawiających się na scenie wiersza jest umownie nakreślony bandyta czyniący przygotowania do zbrodni, jaką stanowi rozbój z użyciem noża. Rozbój, w którego skład wchodzi zabór mienia i zamach na osobę, w przedwojennym prawie karnym był traktowany jako szczególnie groźne, niebezpieczne przestępstwo ${ }^{39}$. Właśnie przeciw takiemu czynowi protestuje głos mówiący w wierszu (pozostając przy filmowej metaforyce, powiemy, że jest to głos z offu, należący nie tylko do narratora, gdyż wyrażający prawdę uznawaną przez całą zbiorowość), na co pada zuchwała, amoralna odpowiedź: „Mam - prawo noża!” - to odpowiednik wyrażeń

36 Tenże, Znaczenie pośrednictwa w metafizyce życia zbiorowego, [w:] tegoż, Szkice..., s. 36-37. Słowa te przywołuje i komentuje J. Zięba, Bolesława Leśmiana światopogląd nowoczesny, s. 96-97.

37 Zob. O. Nawrot, Wprowadzenie do logiki dla prawników, Warszawa 2012, s. 229-230.

38 S. Waltoś, Proces karny. Zarys systemu, Warszawa 2008, s. 20.

39 Kodeks karny z roku 1932 w artykule 259 definiował rozbój w podobny sposób jak dzisiaj, jako przestępstwo złożone z kradzieży i zamachu na osobę. Zob. M. Piątkowska, Życie przestępcze w przedwojennej Polsce. Grandesy - kasiarze - brylanty, Warszawa 2012, s. 136. 
takich jak prawo pięści, siły czy prawo kaduka, nazywających bezprawną przemoc. Właśnie zamach na osobę budzi sprzeciw wyrażony zakazem: „Nie masz prawa..." w stanowiącym synekdochę ekspresywnym sformułowaniu o "ludzkiej gardzieli" ${ }^{\prime \prime}$.

Brak jeszcze w tak zarysowanej scenie pełnej płaszczyzny osobowej, nie doszło nawet do sytuacji, w której „zbój” stanąłby naprzeciw swojej potencjalnej ofiary - natomiast w chwili pojawiania się na horyzoncie sylwetki człowieka, będącego zarazem reprezentantem zbiorowości i uznawanych przez nią zasad, rodzi się radykalnie nowa płaszczyzna - prawna. Na zaśnieżonej ulicy majaczy cień „stróża prawa”, najniższego rangą urzędnika państwowego na służbie. Opisując w ten sposób Leśmianowską scenkę, odwołuję się do nowatorskiej w jego czasach koncepcji jednego z najwybitniejszych teoretyków prawa - Leona Petrażyckiego, absolwenta tej samej uczelni, którą ukończył Leśmian, Uniwersytetu Kijowskiego.

Dzieło Petrażyckiego O pobudkach postępowania i o istocie moralności i prawa, opublikowane po raz pierwszy w roku 1904, zawiera jedną z najbardziej oryginalnych koncepcji, w której prawo traktowane jest jako emocja, co wymaga niestety, jak podkreśla Bartosz Brożek, osobnego języka, gdyż autor definiował emocje w sposób dziś nieprzyjęty ${ }^{41}$. Petrażycki wyróżnił czucia, uczucia i właśnie emocje, mające według niego podwójny, „podrażnieniowopopędowy" charakter, i zakładał, że „ze stanowiska historyczno-ewolucyjnego" ${ }^{\prime \prime 2}$ emocje odgrywały pierwotnie największą rolę w życiu psychicznym człowieka. Zdaniem myśliciela emocje prawne, różniące się od moralnych, są nie mniej powszechne i zinterioryzowane przez ludzi niż te moralne. Mając świadomość uproszczenia, na jakie pozwalam sobie wobec skomplikowanej koncepcji Petrażyckiego, chcę zauważyć, że poetycki przykład, którym posłużył się Leśmian, to wyabstrahowany casus emocji prawnej, bez najmniejszej domieszki emocji moralnej. "Zawodowy” bandyta zareagował na mundur, a nie miał nawet okazji, by przeżyć wstrząs moralny, nie było tu jeszcze potencjalnej ofiary. Tu kończy się analogia, gdyż w wierszu pojawia się obok wymiaru horyzontalnego, inny - wertykalny.

\section{To, co wysokie i to, co niskie}

Przestępca nie ma jeszcze upatrzonej ofiary, nie widzi dobrze twarzy najniższego funkcjonariusza policji, ale sam jego „mundur” - znak przypomina mu cały splot relacji społecznych, w których jest zanurzony, a które

40 Odpowiedzialność za życie Innego jest stałym motywem w poetyckim myśleniu Leśmiana. Pisałam o tym w szkicu Leśmian: Ja i Inny, [w:] Złotnik i śpiewak. Poezja Leopolda Staffa i Bolesława Leśmiana w kręgu modernizmu, Kraków 2009, s. 344-381.

41 B. Brożek, Emocje jako fundament prawa. Uwagi o teorii Leona Petrażyckiego, [w:] Naturalizm prawniczy. Stanowiska, red. naukowa J. Stelmach, B. Brożek, Ł. Kurek, K. Eliasz, Warszawa 2015, s. 253-265. Por. też M. Kik, Leona Petrażyckiego filozofia prawa, "Czasopismo Filozoficzne” 2006, nr 1, s. 52-60.

42 L. Petrażycki, Wstęp do nauki o prawie i moralności, Warszawa 1959, s. 403, cyt. za: B. Brożek, Emocje..., s. 255. 
ignorował, gdy wołał o przysługującym mu rzekomo „prawie noża”. Posterunkowy z wiersza staje się za sprawą munduru „stróżem prawa” i strażnikiem Prawa ${ }^{43}$. Jacques Derrida zauważa, że znajdować się przed prawem to zawsze jedynie być przed jego przedstawicielami: „Człowiek znajduje się więc w obliczu prawa, nawet na nie nie patrząc; może być więc $\mathrm{w}$ jego obliczu, a zarazem nigdy nie wejść z nim w kontakt"44.

Leśmianowski bandyta - tak samo jak niepodobny do niego "niewinny" bohater przypowieści Kafki - spotyka tylko „najniższego ze strażników”, za którym "stoją kolejno strażnicy, jeden potężniejszy niż drugi" ${ }^{\prime 4}$. Dla "człowieka ze wsi" i dla Leśmianowskiego zbója sam widok tego najniższego okazuje się „nie do zniesienia”. Postacie umieszczone przez Leśmiana w ulicznej zimowej scenerii są słabo widoczne, jednak to posterunkowy, powiększony o wysokość chybotliwego cienia, stoi niewzruszenie „na widoku", a zbój tylko wyłania się z ciemności, by uciekać chyłkiem poza ramy kadru. Żaden z nich nie widzi niewidzialnego Prawa, ale obaj mają nad głowami ten sam księżyc i piętrzące się obłoki. W porównaniu z ciężarem gatunkowym Kafkowskiej przy powieści ironiczna lekkość wiersza sprawia wrażenie, że może tu się pojawić nieco Chagallowski obraz Boga „umykającego" przed zbrodniczą ręką.

Żaden z ludzkich bohaterów nie jest określony ogólnym mianem „człowiek”, są "zbójem” i „posterunkowym”, funkcjonując w jednoznacznie rozdanych rolach, wyznaczonych właśnie przez prawo. „Nie instytucja dla człowieka, lecz człowiek dla instytucji. Nie prawo dla jednostki, lecz jednostka dla wypełnienia tego prawa"46 - pisał Leśmian w przywołanym już eseju Znaczenie pośrednictwa..., poddając krytyce „zestandaryzowane” wyobrażenia o przestępcy, które wyłaniają się z norm nowoczesnego prawa:

Nie sama kara, lecz przynależna mu za te zbrodnie o góln i k ow ość kary, jak ciężka zmora, spada na zbyt luźnie zastosowane do niej bary żywego zbrodniarza, pociągniętego do odpowiedzialności nie tyle za swoje własne przestępstwo, ile za umówione z góry wykonanie przewidzianego czynu, włączanego natychmiast do łańcucha przyczyn i skutków, który na kształt łańcucha sędziowskiego dźwiga na swej szyi ten sam człowiek przeciętny ${ }^{47}$.

Interpretacja utworu poetyckiego nie może się jednak upodobnić do ponad stuletnich anegdot o egzaminach, podczas których studenci prawa musieli wykazywać, że w swoim otoczeniu dostrzegają „podmioty i przedmioty prawa". Stosowanie języka prawnego jest uzasadnione tylko o tyle,

43 Ze względu na paralelę Schulz - Leśmian warto zastanowić się nad różnicami w ich podejściu do Kafkowskiego Prawa. Zob. P. Tacik, Schulzi Kafka wobec Prawa, [w:] Schulz. Między mitem a filozofia, pod red. J. Michalik i P. Bursztyki, Gdańsk 2014, s. 67-84.

\footnotetext{
44 J. Derrida, Przed prawem, przeł. J. Gutorow, [w:] Nienasycenie..., s. 212.

45 F. Kafka, Przed Prawem, przeł. J. Ekier, [w:] Nienasycenie..., s. 192.

46 B. Leśmian, Znaczenie pośrednictwa..., s. 32.

47 Tamże, s. 34.
} 
o ile wnosi coś do interpretacji. Scenka uliczna z wiersza to nie tylko ilustracja przekonania Leśmiana o znaczeniu strzeżenia porządku prawnego za pomocą widzialnych, materialnych znaków. Paradoksalnie - to, co zostało ochronione, jest niewidzialne - to czyste życie, wartość życia jako takiego.

Leśmianowski Bóg nie jest strażnikiem, nie wiadomo nawet, czy jest gwarantem ziemskiego prawa. Nie został zabity w czasach po „śmierci Boga”; nie stał się ofiarą zbrodni udaremnionej przez samą obecność "stróża prawa”. Dawno abdykował z pozycji wszechmocnego władcy, a przecież to - na sposób znany zarówno z tradycji żydowskiej, jak i z katolickiego Aktu wiary - Bóg żywy. Wyobrażenie Boga jako ocaleńca jest tu czymś rewelacyjnym, w źródłowym znaczeniu słowa, odsłania bowiem tajemnicę absolutnego, ponadjednostkowego życia. Wizja ta pozwala Leśmianowi uwolnić się od wielu aporii nowoczesności. Jedno zaskakujące, nieoczekiwane słowo, „żywcem”, wprowadza szereg możliwych perspektyw: Bóg nie został ani zabity, ani „schwytany żywcem", pozostał nieuchwytny.

Bóg (postać z poetyckiej przypowieści) bezpiecznie się oddala, natomiast w paralelnej ucieczce w świecie „dolnym” zbój pogrąża się w „nicości” i niekoniecznie jest to nicość jego moralnego zła, może to być również pustka potencjalnego czynu. Inaczej niż u Kafki, gdzie każdy jest niejako winny, u Leśmiana zawodowy przestępca uniknął tym razem nie tylko kary, ale także winy. Bóg nie oskarża go, ale też nie usprawiedliwia, nie został tu wpisany w (ojcowską) rolę sędziego.

W tym miejscu powinna się pojawić najkrótsza choćby dygresja o nożu jako ulubionym „narzędziu zbrodni” reprezentującym u Leśmiana wszystkie inne możliwe przedmioty, które służą do zabijania. W wierszu Wrogowie niepokojąca obecność noża oznacza potencjalną możliwość zamordowania jednego przeciwnika przez drugiego. W utworze Zły jar chodzi o samobójstwo - „nóż” to rzekoma "przyczyna” targnięcia się przez osamotnionego człowieka na własne życie. Leśmian nawiązuje tu między innymi do wypowiadanej w esejach krytyki dosłownie pojmowanej przyczynowości; to, co poprzedza dane wydarzenie, nie powinno być mechanicznie traktowane jako jego przyczyna. „Na lep noża”48 idzie wreszcie bezbronny inteligent, który zderza się „we mgle” ze „zbójem” w jednej z migawek Pejzażu wspótczesnego. Jego przeciwnik, który „uderza w minę”, niekoniecznie atakuje fizycznie, ale nawołuje do nienawiści.

Gdy pominąć utwory pisane prozą, najbardziej skomplikowana i rozbudowana intryga kryminalna związana z przestępstwem z użyciem noża odtwarzana jest (w ramach swoistej rekonstrukcji wydarzeń przeprowadzanej w zaświatach) przez bohaterów Zdziczenia obyczajów pośmiertnych. Jest tu ofiara i motyw zbrodni, jest też „zabójczyni młoda”, ale okazuje się, że to zdradzona przez Sobstyla Krzemina namówiła swoją rywalkę, Marcjannę, by ta ją zabiła. Tonacja buffo zderza się z tonem wielkiego serio, gdy u Leśmiana mowa jest o metafizycznym wymiarze istnienia.

48 Tenże, Pejzaż współczesny, s. 395. 
Powracam do wiersza. To, co niskie i to, co wzniosłe - dwie kategorie estetyczne i dwie perspektywy spotykają się tu ze sobą ${ }^{49}$. Budowa wersów i rymy tworzą dynamikę utworu, w każdej z czterech kwartyn mamy trzy wersy napisane trzynastozgłoskowcem przeciwstawione ostatniej, krótszej, pięciosylabowej. W początkowej strofie jest to odpowiedź przestępcy przyznającego sobie prawo noża - wers ten rymuje się z pierwszym w strofie. W trzech kolejnych kwartynach ostatni wers łączy się za pomocą rymu z przedostatnim. Przedostatnią strofę zamyka ciężkie, pięciosylabowe, prozaiczne słowo "posterunkowy”, dające się w słowniku poetyckim Leśmiana zestawić jedynie z „ministrem” czy „dziennikarzami” z Pejzażu wspótczesnego, wnosi ono element zaskoczenia, „zatrzymuje” czytelnika, tak jak widok policjanta powstrzymał działanie przestępcy.

W ostatniej strofie zamiast oczekiwanych pięciu sylab mamy odmianę pojawia się tu wers dziesięciosylabowy. Hipotetyczne zdanie „On - olbrzymieje”, które wpisywałoby się w ustanowiony przez trzy poprzednie zwrotki rytm, zamykałoby utwór mocną puentą. Pozbawione takiej dynamiki stwierdzenie „A on - olbrzymiejąc - poważnieje...", zakończone wielokropkiem, wprowadza zwolnienie tempa odpowiadające quasi-realistycznej akcji. Posterunkowy nie podejmuje pościgu za przestępca, nie ma do tego powodu. Wystarczy, że trwa na wyznaczonym dla niego miejscu, a porządek - moralny i prawny - zostanie zachowany.

Warto raz jeszcze przeczytać wiersz Leśmiana na tle utworów z dwudziestolecia międzywojennego, w których Bóg ukazany został jako groźny policjant, strzegący ładu świata. Teksty te zinterpretował Tomasz Cieślak, dowodząc, że w twórczości autorów o orientacji lewicowej był to stały, powtarzający się motyw ${ }^{50}$. Zwłaszcza jeden ze wskazanych przez łódzkiego badacza wierszy, Policjant Aleksandra Wata, może, na zasadzie kontrastu, dopomóc w zrozumieniu stanowiska, jakie zajmuje Leśmian.

Bohater liryczny tego utworu (opublikowanego na łamach „Nowej Kultury” 1924, nr 3) czyni z Boga groźnego policjanta świata. Bóg pilnuje porządku, który sam ustanowił. [...] Świat, jaki im stworzył, jest więzieniem ${ }^{51}$.

W wierszu Wata „prawo” pojawia się jako synonim opresji, mowa jest o „pustej stronicy praw”, a podmiot zapowiada „bliski dzień, gdy zniknie jak krosta / policjant z góry, policjant z rogu" ${ }^{\prime \prime 2}$. W bluźnierczej analogii Bóg jawi się jako bezwzględny stróż porządku. W tym historycznym kontekście

49 Zob. T. Kostkiewiczowa, M. Popiel, Wzniosłość, [w:] Słownik polskiej krytyki literackiej 1764-1918. Terminy - pojęcia - zjawiska - przekroje, pod red. J. Bachórza, G. Borkowskiej, T. Kostkiewiczowej, M. Rudkowskiej i M. Strzyżewskiego, Toruń-Warszawa 2016, t. 2, s. 783-789.

50 T. Cieślak, Bóg i niebo w poezji rewolucyjnej dwudziestolecia międzywojennego, „Acta Universitatis Lodzensis. Folia Litteratia Polonica" 2001, nr 4.

51 Tamże, s. 77.

52 A. Wat, Poezje zebrane, Kraków 1992, s. 163. T. Cieślak przypomina też Zagłębie Dąbrowskie Władysława Broniewskiego, gdzie: „Na rogu stoi policjant, / nad policjantem Bóg”, zob. T. Cieślak, dz. cyt., s. 78. 
widać wyraźnie, że dla Leśmiana sytuacja i cały „pejzaż metafizyczny” rysują się zupełnie inaczej. Jeśli dodać do tego, że jego myśl dotycząca strzeżenia prawa wyrażona została w eseju jeszcze w czasach, gdy porządku pilnował carski policjant, staje się bardziej wyraźne, że motywowany religijnie zakaz „nie zabijaj” jest dla niego nadrzędny i niekwestionowany, niezależnie od niedoskonałości czy nawet opresywności systemów prawnych tworzonych przez ludzi. Mimo niejednoznacznego i groteskowego charakteru utwór nie pozostawia wątpliwości w kluczowej kwestii - nikt nie daje nikomu prawa do tego, by odbierać innym życie. Przy tym nad całą scenką unosi się aura niedopowiedzenia i nie trzeba niweczyć jej nazbyt jednoznaczną interpretacją. Jednak wolno chyba wypowiedzieć następującą konkluzję: ponieważ nie doszło do zabójstwa człowieka, Bóg uniknął tu śmierci, a dzieje się tak dzięki prawu.

Jest też najtrudniejsze pytanie o zapisane dużą literą Prawo. Byłoby ono w tej miniaturze poetyckiej właśnie „samym strzeżeniem”, jak w egzegezie Derridy (nie odważę się powiedzieć: jak u Kafki...) - „prawo to byłoby samym strzeżeniem, już tylko strzeżeniem. Tym jednym spojrzeniem pomiędzy strażnikiem i człowiekiem” ${ }^{23}$. W przypowieści Kafki „z drzwi Prawa bije nigdy niegasnący blask” ${ }^{\prime 2}$. U Leśmiana mamy symetryczny „dolny” blask/brzask latarni i „górny” - białego księżycowego światła. W zakończeniu poetyckiej paraboli czytamy „On olbrzymiejąc - poważnieje...”. On - czyli kto? Posterunkowy, księżyc czy Bóg? To wcale nie jest oczywiste. Nawet jeśli przyjąć, że policjant nosi nazwisko Chmura ${ }^{55}$ (byłoby ono motywowane zarazem realistycznie i alegorycznie), to tego rodzaju założenie również niczego nie przesądza.

Zestawienie niewielkiego wiersza z przypowieścią Kafki wydaje się niekorzystne dla Leśmiana - nie sposób wyczerpać sensu parabolicznej pułapki, jaką pisarz zastawił na czytelnika. Na takim tle myśl Leśmiana wydaje się bardzo czytelna - nikt nie dał nam prawa, by pozbawiać innych życia, nie wolno zabijać, Bóg, żywy Bóg nie jest zabójca, ale zawsze ofiarą. Pozorna prostota wiersza wiąże się z manifestowanym tu ironicznie naiwnym zaufaniem do prawa (i Prawa), strzeżonego przez samotnego policjanta. Optymistyczne zakończenie jest jednak wyjątkiem, nie zaś regułą; tym razem się udało - bandyta odstąpił od swojego zamiaru, nikt nie stracił życia, a Bóg (żywy Bóg) ocalał.

\section{Atak na granice}

Na krótko przed samobójczą śmiercią Gilles Deleuze rozważał absolutne znaczenie życia, znajdując również literackie przykłady sytuacji, w których wartość życia w czystej postaci oddziela się niejako od osoby. W utworze

53 J. Derrida, Przed Prawem, [w:] Nienasycenie..., s. 218.

54 F. Kafka, Przed Prawem, [w:] Nienasycenie..., s. 192.

55 „W ostatniej strofie wiersza [...] spotykają się - księżyc, Bóg, skradający się zbój i posterunkowy Chmura. Niezwykłe jest uzyskane w ten sposób zmieszanie tego, co wysokie, i tego, co niskie, tego, co wzniosłe, i tego, co pospolite". M. Stala, Coś srebrnego dzieje się w chmur dali. Dziesięć uwag o księżycu w poezji Bolesława Leśmiana, [w:] Stulecie "Sadu rozstajnego", pod red. U.M. Pilch i M. Stali, Kraków 2014, s. 376. 
Dickensa Nasz wspólny przyjaciel ukazana jest troska ludzi otaczających łotra spoczywającego na łożu śmierci i ich walka o utrzymanie go przy życiu: „W miarę jednak, jak powraca do świata żywych, jego wybawcy stają się coraz bardziej nieczuli, on sam zaś staje się na powrót grubiański i niegodziwy"56. Zdaniem filozofa, pisarz przedstawił tu w czystej postaci ,jakieś życie", bezosobowe, a przy tym jednostkowe. Swoją refleksję uogólnia następująco:

Nie należy ograniczać życia do pojedynczego momentu, w którym życie jednostkowe stawia czoła powszechnej śmierci. Jakieś życie jest wszędzie, w każdym momencie, przemierzanym przez ten lub inny żywy podmiot i mierzonym przez to, co już przeżyte: życie immanentne, niosące za sobą wydarzenia lub osobliwości, które jedynie aktualizują się w podmiotach i przedmiotach. Owo niezdefiniowane życie samo w sobie nie ma nawet tak bliskich sobie momentów, lecz jedynie między-czasy, między-momenty ${ }^{57}$.

Słowa myśliciela, który był również komentatorem Bergsona, dobrze oddają to, co poezja XX wieku wyrażała w sposób niedyskursywny, a co Leśmian ujmował w wierszach-przy powieściach. Dwa kontrastowe przykłady: stylizowany poemat Asoka i nowoczesny "pejzaż metafizyczny” pozwalają zobaczyć ten sam zakaz „nie zabijaj" wpisany w przekonanie o wartości życia - niezależnie od tradycji, buddyjskiej i judeochrześcijańskiej. Żaden z utworów nie mówi o "człowieku pierwotnym”, w żadnym to, co ludzkie, nie jest „naturalne" - oba są całkowicie, choć na różny sposób, zanurzone w kulturze i w tym, co społeczne. Przy wszystkich oczywistych różnicach z przyjętej tu perspektywy ważną rolę odgrywa fakt, że odmienna w obu wierszach jest relacja człowiek - prawo. Uwewnętrzniony imperatyw etyczny uczyniony obowiązującą zasadą przez starożytnego władcę i zewnętrzny impuls dwudziestowiecznego przestępcy wobec znaku przypominającego o normach prawnych różnią się radykalnie, tak samo jak balladowy, baśniowy poemat nie przypomina groteskowej ulicznej migawki.

W tym miejscu otwiera się możliwość dalszych rozważań o relacjach między myślą Leśmiana a zagadnieniami prawnymi, zwłaszcza filozofią prawa. Jeden $z$ najgłębszych problemów wiąże się ze wzniosłym sensem prawa i samego myślenia prawnego jako wyznaczania granic, jako czynności dzielenia i łączenia. Leśmian zgodziłyby się z Simmlem, że: „Tylko człowiekowi - w odróżnieniu od natury - dane jest łączyć i rozdzielać i to w szczególny sposób, mianowicie tak, że jedno jest zawsze warunkiem drugiego" ${ }^{\prime 58}$. Spodobałaby mu się zapewne następująca myśl:

\footnotetext{
56 G. Deleuze, Immanencja: życie..., przeł. K.M. Jaksender, Kraków 2017, s. 17.

57 Tamże, s. 19-20.

58 G. Simmel, Most i drzwi. Wybór esejów, przeł. M. Łukasiewicz, Warszawa 2006, s. 248.
} 
Człowiek jest istotą łączącą, która zawsze musi rozdzielać, aby móc łączyć - toteż gołe, neutralne istnienie dwóch brzegów musimy najpierw duchowo ująć jako rozdział, aby połączyć je mostem. Człowiek jest też istotą, która potrzebuje granic i nieustannie je przekracza. Domostwo zamknięte drzwiami oznacza wprawdzie, że z nieprzerwanej jedności naturalnego bytu człowiek wydziela kawałek dla siebie. Ale nieforemna nieskończoność bytu przybiera kształt dopiero dzięki ludzkiej zdolności ograniczania i podobnie granice, jakie człowiek nieustannie sobie zakreśla, zyskują sens i godność dopiero dzięki temu, co unaocznia ruchomość drzwi: dzięki temu, że człowiek w każdej chwili może z tego ograniczenia wyjść na wolnośćs9.

\section{B I B LIO GR A F I A}

Anidjar G., Znaczenie życia, przeł. T. Bilczewski i A. Kowalcze-Pawlik, [w:] Teoria, literatura, życie. Praktykowanie teorii w humanistyce wspótczesnej, pod red. A. Legeżyńskiej i R. Nycza, Warszawa 2012.

Bielik-Robson A., Erros. Mesjański witalizm i filozofia, Kraków 2012.

Brożek B., Emocje jako fundament prawa. Uwagi o teorii Leona Petrażyckiego, [w:] Naturalizm prawniczy. Stanowiska, red. naukowa J. Stelmach, B. Brożek, Ł. Kurek, K. Eliasz, Warszawa 2015.

Deleuze G., Immanencja: życie..., przeł. K.M. Jaksender, Kraków 2017.

Fedirko J., Kandaharskie inskrypcje króla Aśoki, „Peregrinus Cracoviensis” 2014, nr 2.

Głowiński M., Zaświat przedstawiony. Szkice o poezji Bolestawa Leśmiana, Warszawa 1981.

Jakubowiak M., Nieuchronny plagiat. Prawo autorskie w nowoczesnym dyskursie literackim, Warszawa 2017.

Kik M., Leona Petrażyckiego filozofia prawa, "Czasopismo Filozoficzne” 2006, nr 1.

Krzyżowski J., Legendy króla Asioki, [b.m.] 2005.

Leśmian B., Poezje zebrane, oprac. J. Trznadel, Warszawa 2010.

Leśmian B., Szkice literackie, oprac. J. Trznadel, Warszawa 2011.

Marczewska-Rytko M., Asioka jako twórca buddyzmu społecznego, "Annales UMCS" 1997, vol. 4.

Markowski M.P., Życie, pieszczota, sztuka, śmierć, [w:] „Lecz nie było już świata...", red. A. Nowakowski, Kraków 2017.

Marlewicz H., Leśmian - indyjskie inspiracje, „Perspektywy Kultury” 2009, nr 1.

Milewska I., The "Mahabharata" Epic, Its Translations and Its Influence on Polish Intellectual Circles and General Readers, "Iuvenilia Philologorum Cracoviensium” 2012, t. 5 .

Orędzia króla Asioki, przeł. J. Makowiecka, Warszawa 1964.

Nienasycenie. Filozofowie o Kafce, red. Ł. Musiał i A. Żychliński, Kraków 2011.

59 Tamże, s. 255. 
Nycz R., Wielowyktadalność. Symboliczne alegorie Leśmiana, [w:] R. Nycz, Tekstowy świat. Poststrukturalizm a wiedza o literaturze, Kraków 2000.

Piątkowska M., Życie przestępcze w przedwojennej Polsce. Grandesy - kasiarze - brylanty, Warszawa 2012.

Sienkiewicz B., Filozofia życia vs. Koncepcja mechanistyczna. Od filozofii życia do posthumanizmu. Przypadek Leśmiana i Schulza, [w:] Młodopolski witalizm, modernistyczne witalizmy, pod red. A. Czabanowskiej-Wróbel i U.M. Pilch, Kraków 2016.

Simmel G., Most i drzwi. Wybór esejów, przeł. M. Łukasiewicz, Warszawa 2006.

Strong J., The Legend of King Aśoka. A Study and Translation of Asokāvadāna, Delhi 2008.

Szczerbowski A., "Brzegiem szału w niepojętość zieloności”. O „Łące” Bolesława Leśmiana, Warszawa 1934.

Tacik P., Schulz i Kafka wobec Prawa, [w:] Schulz. Między mitem a filozofia, pod red. J. Michalik i P. Bursztyki, Gdańsk 2014.

Tuczyński J., Motywy indyjskie w literaturze polskiej, Warszawa 1981.

Waltoś S., Proces karny. Zarys systemu, Warszawa 2008.

Zięba J., Bolestawa Leśmiana światopogląd nowoczesny. O eseistyce poety, Kraków 2000.

Zięba J., Pieniądz i stowo. Nowoczesne paradoksy Leśmianowskiego języka poetyckiego, „Teksty Drugie” 2010, nr 6.

\section{STRESZCZENIE}

W eseistyce Bolesława Leśmiana, absolwenta studiów prawniczych, zwraca uwage nie tylko obecność kontekstu filozoficznego czy socjologicznego, ale także prawnego, podczas gdy jego poezja wydaje się całkowicie odległa od zagadnień prawa. $\mathrm{W}$ zaproponowanej $\mathrm{w}$ artykule interpretacji dwóch niepodobnych utworów poetyckich, ballady Asoka z tomu Łąka i wiersza o incipicie „Przez śnieżycę, co wyjąc powiększa przestworza” z tomu Dziejba leśna, ukazana zostaje kwestia prawnej ochrony wartości, jaką stanowi życie. Władca i prawodawca starożytnych Indii, Aśoka, zagwarantował ją w swoich orędziach. Bohaterowi licznych legend otwiera to drogę do tego, co duchowe. W XX wieku wartości ludzkiego życia strzeże „przedstawiciel prawa”, umundurowany policjant, którego sama obecność na ulicy udaremnia rozbój. W obu przypadkach życie traktowane jest przez Leśmiana jako najwyższa wartość, motywowana metafizycznie, co otwiera drogę do dalszych rozważań dotyczących wzniosłości prawa w rozumieniu poety, a także do pytania, czy zagadnienie związków literatury i prawa, znane z badań nad twórczością Franza Kafki, może pomóc w zrozumieniu światopoglądu Bolesława Leśmiana.

\section{Słowa kluczowe}

poezja Bolesława Leśmiana, eseistyka Bolesława Leśmiana, prawo a literatura, witalizm, wartość życia 


\section{S UMMARY}

\section{Leśmian before the Law. The value of life and the grandeur of law}

Essay writing by Bolesław Leśmian, a graduate of law, draws attention not only to the presence of the philosophical or sociological context but also the legal one while his poetry seems to be completely detached from legal practice. The issue of legal protection of values represented by life is depicted in the interpretation of two dissimilar poetic works, namely the ballad Asoka from the volume Łaka (The Meadow) and the poem starting with the words "Przez śnieżycę, co wyjąc powiększa przestworza" from Dziejba leśna (Forest Happenings). Aśoka, a monarch and lawmaker in ancient India, guaranteed it in his addresses. It paths the way to the spiritual for the hero of many legends. In the 20th century the value of human life is guarded by "a representative of law", uniformed police officer whose very presence in the street prevents robbery. In both cases life is treated by Leśmian as the highest value motivated metaphysically, which opens the way for further reflections concerning the grandeur of law as understood by the poet as well as to the question whether the issue of connections between literature and law, already known from the research into the literary output of Franz Kafka, may help understand Bolesław Leśmian's outlook on life.

\section{Keywords}

Bolesław Leśmian's poetry, Bolesław Leśmian's essay writing, law versus literature, vitalism, value of life 